of valuable papers published by the International Council and by the Fishery Board for Scotland (now the Fisheries Division, Scottish Home Department), two of the most important being "The Haddock Stocks "of the North-East Atlantic" and "The Rate of Mortality in the North Sea Haddock Stocks"the latter a definite contribution to the overfishing problem. These researches gained for him the D.Sc. in 1937. In 1939 he was appointed Buckland lecturer for 1940 to deliver a series of lectures on the haddock, but owing to the outbreak of war the lectures were never delivered.

Raitt was a fellow of the Linnean Society and of the Royal Society of Edinburgh and published papers on various aspects of marine life in different scientific journals. In one of these he described a new species of sandeel from British waters-no mean achievement these days.

$\mathrm{He}$ had a great gift for organizing and staging shows and was largely responsible for two fishery exhibits put up by the Fishery Board for Scotland at Aberdeen and Glasgow, which wøre designed to illustrate the practical aspect of marine research as carried out by a Government department. The film "Sea Food", a record of the methods carried out at sea by the research vessels and in the laboratory, was also supervised by him.

During the present War, he was seconded to the Ministry of Home Security and held important posts under the district commissioners at Inverness, Edin- burgh and Dundee.

$\mathrm{H}_{\Theta}$ is survived by Mrs. Raitt and two sons.

R. S. Clark.

\section{Prof. Gustav Cassel}

Prof. Gustav Cassex, whose death at the age of seventy-eight occurred on January 14, was beyond doubt one of the outstanding figures in economic science during the inter-war period. His authority was second only to that of Lord Keynes, and his advice was eagerly sought on many occasions by his own Government and by foreign Governments. $\mathrm{H}_{\Theta}$ played an active part at many international monetary conferences during the 'twenties and early 'thirties, and was head of the Swedish delegation to the World Economic Conference of 1933.

Prof. Cassel occupied the chair of economics at the University of Stockholm, and his "Theory of Social Economy" will always rank with the outstanding works on economic theory. First and foremost, however, he was a monetary specialist. His most important contributions to economic science were in the monetary sphere. In particular, he secured his place in posterity as the leading theoretical expert on foreign exchange during the chaotic period that followed the War of 1914-18. In his "Money and Foreign Exchange After 1914", he put forward the theory that under a system of inconvertible paper currencies the exchange-rates tend to represent the ratio between the internal price levels of the countries concerned ; in other words, they tend to adjust themselves towards what he called their "purchasing power parities". When he first sought to popularize this conception, it was regarded as almost revolutionary, and the time-honoured theory according to which exchange-rates are determined by the trade balance died hard. He lived to see, however, the general acceptance of his principle.

In the sphere of monetary policy, Cassel was strongly opposed to deflation, and advocated low interest-rates during the late 'twenties and early 'thirties. As a member of the Gold Committee of the League of Nations, and in his various. writings, he was concerned by the inadequacy of the volume of monetary gold to meet the requirements of expanding world production and trade. In 1937, however, Prof. Cassel, together with many other theoretical and practical experts, was misled by an apparent excess of gold supplies into a panicky advocacy of a deflationary policy.

Prof. Cassel did not believe in the device, so popular among many economists, of seeking to impress his readers by indulging in obscurantism. His books and articles were written for the most part in simple, clear language, understandable to the intelligent layman at the same time as being inspiring to the expert.

P. EINZIG.

\section{Mr. E. Rothbart}

ERwiN RothbaRt, acting lecturer in economic statistics in the University of Cambridge, who was killed in action in Holland in December 1944, aged thirty-one, was a refugee from Nazi Germany and an expert in economic theory and statistics; he specialized in the theory of industrial fluctuations and economic development.

Despite his originality, he had published little: his reticence and his horror of superficiality were such that his best work is probably to be found in the mass of unpublished manuscripts which he left. Some of these may be rescued for publication, but undoubtedly the more subtle of his ideas were still locked away in his mind. The quality of his thought was revealed in the penetrating book-reviews which he contributed to the Economic Journal, and in the formal and informal discussions on economic theory in which he took part with the younger economists at Cambridge and London.

Rothbart first became prominent in discussions in 1936 at the meetings held regularly by Profs. Robbins and Hayek at the London School of Economics. There, with A. P. Lerner, O. Lange, N. Keldor and M. Kalecki, he found himself one of a small group championing the latest theories of J. M. Keynes with an almost religious insistence. Two years later he was appointed research assistant in economic statistics at Cambridge, and in 1940 he took over the teaching of economic statisties, and continued it until he insisted on joining the Army.

Rothbart was a fine example of that combination of opposites, which is the rule rather than the exception in the workings of the human mind. Quick in thought, he was slow in action and self-expression. A self-taught mathematician, he delighted in the subtler turns of economic theory; yet his awareness of practical and political realities was no less acute. A lover of liberal values, his political sympathies were nearer to the hard discipline of the communists : with an impish love of life, he combined a recklessness that courted death. He leaves a widow and young son.

D. G. Champernowne.

WE regret to announce the following deaths:

Dr. Alexander Duckham, chairman and governing director of Alexander Duckham and Co., Ltd., lubrication technologists, on February 1, aged sixty-seven.

Prof. S. H. Gage, since 1908 emeritus professor of histology and embryology at Cornell University, on October 20, aged ninety-three. 